Output, Inflation and Growth

AN INTRODUCTION TO MACRO-ECONOMICS 


\section{Output, Inflation and Growth}

AN INTRODUCTION TO

MACRO-ECONOMICS

SECOND EDITION

D. C. Rowan

PROFESSOR OF ECONOMICS, UNIVERSITY OF SOUTHAMPTON

Macmillan Education 
(C) D. C. Rowan 1968, 1974

All rights reserved. No part of this publication may be reproduced or transmitted, in any form or by any means, without permission

First edition 1968 Second edition 1974

Published by

THE MACMILLAN PRESS LTD London and Basingstoke Associated companies in New York Dublin Melbourne Johannesburg and Madras

ISBN 978-0-333-16629-1ＩSBN 978-1-349-86173-6 (eBook) DOI 10.1007/978-1-349-86173-6

The paperback edition of this book is sold subject to the condition that it shall not, by way of trade or otherwise, be lent, resold, hired out, or otherwise circulated without the publisher's prior consent, in any form of binding or cover other than that in which it is published and without a similar condition including this condition being imposed on the subsequent purchaser. 
To My Wife 


\section{Contents}

FOREWORD TO THE SECOND EDITION 12

FOREWORD TO THE FIRST EDITION 13

Note AND ACKNowledgements 14

PREFACE 15

1 The SCOPE OF THIS BoOK 19

2 The Process of Economic Analysis 28

3 Definition of Concepts and Measurement of OUTPUT 43

4 National Income and National Product 53

1. National Output or National Product 53

2. National Expenditure 55

3. National Income and Depreciation 55

4. The Introduction of Government 57

5. The Introduction of International Trade 61

6. The Saving-Investment Identity 64

7. Money and 'Real' Values 67

5 OUtPut AND CAPACITY 74

1. The Determinants of Capacity 76

2. The Slope of the Production Possibility Curve 77

3. The Three Problems 82

6 A Sketch of British Economic Experience 87

1. Output, Capacity and Employment 87

2. Prices and Money Wages 93

3. Interest Rates 96

4. The Allocation of Output 97

5. The Balance of Payments on Current Account 102

6. Observations and Theory 105

7 Analytical and Expository Devices 109

1. The Concept of a Function 109

2. Graphs 115

3. The Concept of Elasticity 117

4. Functions and Schedules 123

5. Equations and Identities 128

6. Stocks and Flows 129

7. The Concept of Equilibrium 130

8. Statics and Dynamics 132 
8 The Determination of Equilibrium Output 139

1. Output, Employment and Business Decisions 139

2. The Saving and Investment Analysis 148

3. The Basic Postulate of the Saving and Investment Analysis $\quad 152$

4. Summary 155

9 The Consumption Function and the MultiPLIER 158

1. The Aggregate Consumption Function 159

2. The Propensity to Consume and its Formal Properties 163

3. The Determination of the Equilibrium Level of Output 167

4. The Multiplier and the Marginal Propensity to Consume

10 The Investment Function 182

1. Investment Decisions

2. The Demand for Capital and the Marginal Efficiency of Investment Schedules

3. Investment Demand Schedule

4. The Investment Function

5. The Rate of Interest and the Cost of Funds

6. Some Final Problems

11 Liquidity Preference and the Theory of INTEREST

1. Assumptions and Definitions

2. An Outline of the Liquidity Preference Theory of Interest

3. The Four Demands for Money

4. The Demand for Money and the Interest Rate

200

12 The Theory of Income Determination

1. Characteristics of the Model: Goods Market

2. Characteristics of the Model: Money Market

3. The Complete Model

4. What the Model Predicts

5. Weakness of the Model

13 The Public Sector and the International SECTOR

1. The Public Sector

2. Elements of Fiscal Policy

3. The International Sector

14 Money, Debt and Liquidity 274

1. The Functions of Money 274

2. The Characteristics of Modern Money 276 
3. Money as Debt 278

4. Debts and Liquidity 281

5. Summary 284

15 Commercial Banks and the Money Supply 287

1. Commercial Banks: Definition and Functions 287

2. Deposit Creation in which the Commercial Banks are Active 291

3. Deposit Creation in which the Commercial Banks are Passive

4. Several Commercial Banks

16 Central Banking and the Money Supply 303

1. The Central Bank and its Functions 303

2. The Control of Commercial Bank Cash: Open Market Operations

3. Controlling Bank Cash: Other Devices 313

4. Lender of Last Resort 316

5. Government Fiscal Operations and Debt Management 321

6. Summary

17 The Theory of The Price Level 327

1. Price Determination and Profit Maximisation 327

2. The Production Function and the Marginal Product of Labour

3. The Aggregate Supply Function

4. The Aggregate Demand Function

5. A Numerical Example of the Construction of Aggregate Demand and Supply Schedules

6. The Determination of Prices

7. Inflation and Money Wage Changes 347

8. Preliminary Summary 354

9. The Quantity of Money and the Price Level 358

10. Final Summary 360

Ap pendix: On Alternative Aggregate Demand Curves 366

17* The Quantity Theory of Money 373

1. The Elements of the Quantity Theory 373

2. The 'Monetarist' Position: short-run implications 378

3. The 'Monetarist' Position: long-run implications 383

4. Summary 383

18 Keynes and His Predecessors 389

1. The Structure of the Model 389

2. Pre-Keynesian Macro-Economics 394 
3. Keynesian and Pre-Keynesian Macro-Economics: the 'Keynesian Revolution' 401

4. Summary

19 ECONOMIC GROWTH

408

1. The Definition of Economic Growth 410

2. The Growth of Productive Capacity 411

3. A Production Function Hypothesis 412

4. The Growth in Output and Capacity Output 416

5. Accelerating Growth: Capital Accumulation 418

6. Accelerating Growth: Labour Input 421

7. Accelerating Growth: Innovation 423

8. Summary 424

20 Fluctuations in Economic Activity 428

1. The Terminology of Fluctuations 430

2. Elements of Cycle Theory 434

3. The Dynamic Theory of Investment: the Accelerator Hypothesis

4. Ceilings and Floors

5. Growth and Fluctuations

6. The Balance of Payments in the Cycle

7. More about the Ceiling

448

448

8. Summary

451

454

21 Rising Prices and Inflation 459

1. Inflation and Market Behaviour 461

2. An Inflationary Process: Type 1

3. An Inflationary Process: Type $2 \quad 470$

4. The Inflationary Mechanism in the United Kingdom 472

5. Cost and Demand Inflation 476

6. The Control of Inflation 479

7. Explosive Inflations and Expectations 481

8. Recent Experience and Expectations 482

9. Summary 484

22 Economic Analysis and Economic Policy 489

1. The Aims of Macro-Economic Policy 492

2. The Instruments of Policy 498

3. Controlling Aggregate Demand: Monetary and Fiscal Policy $\quad 502$

4. Summary 504

23 The Modelin Action: Economic Stabilisation 508

1. Economic Stabilisation and Aggregate Demand: Conditional Forecasting

2. The Target Rate of Expansion 
3. The External Constraint 515

4. The Selection of Policies 518

24 Economic Stabilisation: The Use of MoneTARY POLICY 521

1. Monetary Variables 521

2. Monetary Variables and Aggregate Demand: A Preliminary Sketch

3. Monetary Policy and Consumption

4. Monetary Variables and Private Investment

5. Monetary Policy and the Balance of Payments

6. The Technique of Monetary Policy

7. More Dynamics

8. Monetary Policy: Conclusions

25 Economic Stabilisation: The Use of Fiscal PoLICY

1. The Characteristics of Fiscal Policy

2. The Dynamic Multiplier and Fiscal Policy

3. Other Objectives and the External Constraint

4. Summary

INDEX 


\section{Foreword to the Second Edition}

THE revisions incorporated in this new edition are mainly those suggested by the numerous helpful critics among the book's users. Thus Chapter 10 (The Investment Function) and Chapter 17 (The Theory of the Price Level) have both been substantially revised while a new chapter has been written to provide a rather fuller account of the Quantity Theory of Money (Chapter 17*). At the same time a number of minor errors in Examples and Questions have been eliminated and references added to recent empirical work. I cannot acknowledge individually all those, both teachers and students, who have written to me pointing out possible improvements. I do, however, offer them all my sincere thanks. I can only hope they notice an improvement and, if they detect new or remaining errors, will continue to call them to my attention.

Most of the figures and tables have now been taken up to the end of 1970. However, where, as for example in Chapters 23-5, the data is illustrative of a method rather than primarily descriptive, I have left things as they were. At the same time I have not expanded Chapters 16 and 24 to take account of the new techniques of control adopted by the Bank of England in the autumn of 1971, since our experience of these new techniques is as yet too limited to permit us to draw useful conclusions.

Finally the book has benefited considerably from the criticisms and suggestions of Professor Thomas Mayer, who collaborated with me on the U.S. edition. To him I gladly acknowledge a deep debt of gratitude.

D. C. ROWAN 


\section{Foreword to the First Edition}

THIs book was begun as long ago as 1955 when I held a lectureship at the University of Melbourne. Like most texts it developed from a lecture course - in this case an introduction to macro-economics which I then gave. In 1956 I moved to the University of New South Wales (then the New South Wales University of Technology) and by then the first draft was nearly two-thirds complete.

At New South Wales it was, for various reasons, impossible to complete the text. The finished chapters, however, were used as the basis for an introduction to macro-economics which formed part of the first-year economics course for those reading for the Bachelor of Commerce degree.

In 1960 I returned to the U.K. and took up my present appointment at the University of Southampton. By 1964 it became possible to work on the book again and, by 1965 , the basic draft was, at long last, complete. Since the end of 1965 I have undertaken considerable revisions.

In the task of revision I have been greatly helped by the constructive criticisms of those economists who have so generously read the book in whole or in part. So many economists have helped me in this way that I cannot thank each individually. I must, however, record particularly deep debts of gratitude to J. M. Fleming (University of Bristol); C. S. Soper (University of Melbourne); A. J. Hagger (University of Tasmania); E. B. Butler (University of Sheffield); and A. G. Ford (University of Warwick). Those defects which the book still retains must be attributed entirely to the shortcomings - and the obstinacy - of the author.

My thanks are also due to Dr Shipra Dasgupta, Mr D. Crossfield and Mrs E. Rick, who prepared many of the tables and diagrams, and to Mrs P. Dunn, who has so painstakingly and patiently typed the many drafts and revisions.

I am also particularly grateful to Miss Diana Marshallsay, who was not only responsible for the Index but who also gave me immense help with the checking of proofs.

Finally I must record my debt to the many undergraduates of Melbourne, New South Wales and Southampton who, over the eleven years in which the book has been in preparation, have taught me so much about the way in which introductory courses should be taught.

\section{University of Southampton}

D. C. ROWAN

January 1968 


\section{A Note on Statistics}

MANY of the figures in this book employ published economic statistics relating to the British economy. In each case I have followed the usual practice and given a reference to the source whether official or unofficial.

Every care has been taken to make the figures and their reproduction as accurate as possible. Readers are, however, warned that because of minor differences in series, the inevitable revisions which are made from time to time in published economic data and the difficulties of reproduction, the figures should be taken as illustrative of economic behaviour rather than precise quantitative descriptions of it.

\section{Acknowledgements}

THE author and publishers would like to thank the following for their kindness in granting permission: The Clarendon Press, for material from 'The Interrelationship between Costs and Price Changes 1946-1959', by L. A. Dicks-Mireaux, from Oxford Economic Papers, 1961; H.M. Stationery Office, for material from Economic Trends; International Monetary Fund, for material from International Financial Statistics, Supplement to 1963/64 issues; The National Institute of Economic and Social Research, for material from the National Institute Economic Review; and The Times, for material from The British Economy: Key Statistics, 1900-66. 


\section{Preface}

THE primary purpose of this book is to provide an introduction to macro-economics suitable for undergraduates in the first year of a degree course in Economics or Social Science. Despite this, the book should be useful to schools and other educational institutions and some professional bodies, for I have tried, as best I can, to keep the language and exposition simple and $I$ have assumed that my readers have no previous acquaintance with the subject.

The approach of the book emphasises that economics is a social science which aims to develop testable predictions in terms of measurable concepts. Though it contains a good deal of theory, I have tried consistently to develop the view that theory is meant to be tested. To this end each chapter is supplemented by questions and exercises many of which require the reader to select data from published sources and use it to make simple tests of economic predictions or hypotheses. This means that the student is asked not only to read through the book but also to work through it. It also gives the student the opportunity to learn economics in the best of all possible ways - by working out problems for himself. By this approach I hope not only to encourage an appropriate methodological outlook but also to discourage the student from thinking, as many students do, that economic theory is empty and arid and applied economics mainly unstructured description only loosely related to theory.

Many students are drawn to economics initially by an entirely natural and creditable concern with social problems. Unfortunately many introductory courses, in their anxiety to give an adequate grounding in theory, devote little time to the application of theory to policy issues. The result is sometimes disenchantment. I have tried, by devoting the last four chapters of the book explicitly to short-run policy, to give the reader ample opportunity to apply the theory of the earlier chapters to policy problems. In these chapters I have placed the emphasis on the difficulty of conducting macro-economic policy rather than the capacity of a relatively simple theory to grind out apparently satisfactory answers to complex questions.

Economics is commonly studied by many students who do not continue the subject after completing their ' $A$ ' level examination or 
the first year of their university course. With this in mind I have tried to make this book self-contained in the sense that those who read and use it properly should be able to take an informed and critical interest in such valuable publications as Economic Trends and the N.I.E.S.R. Review. At the same time, since many students do proceed further in economics, I have sought to provide a suitable foundation for further work in macro-economics. In particular I have tried to avoid teaching, in the interests of simplicity, things which must subsequently be untaught. At the same time I have tried to avoid concealing difficulties.

Two problems inevitably face the writer of any introductory text: the first and most awkward of these is to decide what use to make of mathematics; the second is how far to describe the institutional framework within which the theory is developed.

As far as the first problem is concerned, the decision taken is to assume no knowledge of mathematics beyond that required for the G.C.E. ' $O$ ' level and, in particular, no knowledge of the differential calculus. This point is important, for many people are discouraged from any systematic study of economics by the belief that the subject is now accessible only to well trained mathematicians. Obviously those who possess a grasp of mathematical methods of analysis, the most powerful tools for thinking yet developed, are in an advantageous position. Nevertheless it remains true that ' $O$ ' level mathematics is enough for the whole of this book.

Not infrequently the fear of mathematics is misplaced. What looks like 'mathematics' is simply the plentiful use of symbols (rather than words) and the frequent employment of the notion of a function. Few students would regard as unintelligible the proposition that 'consumption depends upon income'. Many, however, regard as 'mathematics', and therefore incomprehensible, the statement $C=f(Y)$. I have attempted to eliminate this 'pseudo-fear' or 'symbol phobia' by two methods. The first is to devote a chapter to discussing and illustrating the use of symbols, functions and identities. The second is to use symbols and functional notation wherever I can in the hope, which my experience suggests to be not entirely unjustified, that growing familiarity with this means of expression (which is becoming increasingly common in the literature and the texts) will breed confidence in its interpretation. To some readers the result may seem excessively formal, pedantic or even forbidding. I believe it represents a sensible way of meeting an awkward and unavoidable problem.

As regards the description of institutions I have, after a good deal of cogitation, decided that this must be kept to a minimum. As a result there is very little institutional material (in the narrow sense) 
in the text. There is, however, a good deal in the questions and exercises in that, where appropriate, questions have been devised which require the reader to relate the theory of the text to the behaviour of particular groups of institutions. This may not prove to be the ideal decision, but in view of the high opportunity cost of including purely descriptive matter it is the one I find most strongly supported at the moment.

Structurally the book is divided in the following way. Chapters 1-18 develop a predominantly static model of the macro-economic system. Since most people who embark on economics think, instinctively, in dynamic terms, the static nature of the analysis is given continuous emphasis. Chapters 19-21 are explicitly dynamic. The first gives a short discussion of some aspects of economic growth, emphasising the supply side of the problem and making use of the familiar, but to many objectionable, concept of the production function. The second gives a brief account of the cycle; the third discusses the problem of rising prices with special reference to British experience. Finally, Chapters 22-25 seek to relate the analysis of the earlier chapters directly to problems of policy, not in the sense of providing solutions or showing, with full benefit of hindsight, how much better things might have been managed than they were, but in order to show the very formidable difficulties of conducting macroeconomic policy in a dynamic world.

Analytically the book is planned to follow what might be called 'the principle of increasing difficulty'. In the early chapters basic ideas are spelled out in considerable detail; there are many illustrations and not a little repetition. As the book proceeds, the reader is assumed to acquire facility with economic analysis. Exposition becomes briefer and the demands placed upon the reader more severe but never, I hope, too severe.

Though the book is conceived as a whole it can be argued that the explicit introduction of dynamics coupled with the "principle of increasing difficulty' make Chapters 19-21 unsuitable for inclusion in an introductory course. Those who take this view can, if they wish, omit these chapters. In doing so, however, they incur two severe costs. The first cost arises because, though Chapters 22-25 can be studied without Chapters 19-21, they present greater difficulty when treated in this way. The second cost arises because the omission of Chapters 19-21 removes from the course all discussion of growth, the cycle and rising prices - the three subjects which, at one level or another, students find continuously under debate in the daily press and on television. In my view the loss in realism and continuity resulting from the omission of Chapters 19-21 is not offset by any 
worthwhile gain in simplicity and I believe that most benefit will be obtained from the book by using it as a whole.

Just as the exercises are an integral part of the book, so too are the reading lists which follow each chapter. Wherever possible three types of references have been given: first, there are references which supplement the work of the text; second, there are references which provide an alternative approach to that presented in the text; third, there are references to more advanced treatments of problems discussed in the text.

The reading lists have been kept deliberately short. On the other hand, because of the strains at present imposed upon university and other libraries, alternative references have been provided wherever possible.

In addition to using these references systematically, readers are strongly urged to cultivate the habit of consulting both the monthly Economic Trends and the quarterly reviews published by the Bank of England and the National Institute of Economic and Social Research. The latter publication (referred to hereafter as the Economic Review) is available to students at a specially reduced rate of subscription. For those embarking on the study of macro-economics, purchase of a student subscription is very strongly recommended.

Economics, though a difficult and, at present, regrettably imprecise subject, is nevertheless exciting and rewarding. I hope that, if they use this book well, readers will find that some of the excitement of economics has communicated itself to them. 